\title{
PEMANFAATAN KACANG MERAH (Phaseolus vulgaris L) PADA PEMBUATAN KECAP MANIS
}

\author{
Oleh : Ir.Yurnalis, $M P^{*}$
}

*Dosen di Fakultas Pertanian Universitas Ekasakti

\begin{abstract}
ABSTRAC
Soy sauce is a liquid fermented vegetable or animal protein with high protein in a salt solution and is currently not used as a source of protein but more for flavoring purposes. This study aims to determine the level of substitution of red beans that produce red soy sauce according to quality standards and preferred by consumers. This research has been carried out at the Basic Laboratory of Ekasakti Padang University and ATIP in August to September 2006. The raw materials used are red beans, and other additives. Chemicals are used for chemical analysis accompanied by laboratory equipment.

The results of the study: (1) protein content to the level of soybean substitution with red beans by $30 \%$ still meet the quality requirements of red soy sauce according to the Soy Sauce Quality Standard (SII), (2) the amount of red soy sauce mold at all levels of soybean substitution with red beans meets the standards required, and (3) the level of consumer preference (organoleptic test) on the resulting sweet soy sauce decreases as the use of soybeans decreases, ranging from normal to like.
\end{abstract}

Keywords: soy sauce, red beans, soybeans

\begin{abstract}
ABSTRAK
Kecap adalah cairan hasil fermentasi bahan nabati atau hewani berprotein tinggi di dalam larutan garam dan saat ini sebenarnya bukan dimanfaatkan sebagai sumber protein tetapi lebih banyak untuk tujuan pangan penyedap. Penelitian ini bertujuan untuk mengetahui tingkat substitusi kedele dengan kacang merah yang menghasilkan kecap manis sesuai standar mutu dan disukai konsumen. Penelitian ini telah dilakukan di Laboratorium Dasar Universitas Ekasakti Padang dan ATIP pada bulan Agustus sampai September 2006. Bahan baku yang digunakan adalah kedele, kacang merah, dan bahan tambahan lainnya. Bahan kimia digunakan untuk analisa kimia yang disertai dengan peralatan laboratorium.

Hasil penelitian : (1) kadar protein sampai tingkat substitusi kedele dengan kacang merah sebesar 30\% masih memenuhi syarat mutu kecap manis menurut Standar Kualitas Kecap (SII), (2) jumlah kapang kecap manis pada semua tingkat substitusi kedele dengan kacang merah memenuhi standar yang disyaratkan, dan (3) tingkat kesukaan konsumen (uji organoleptik) terhadap kecap manis yang dihasilkan menurun sejalan dengan berkurangnya penggunaan kedele, berkisar antara biasa sampai suka.
\end{abstract}

Kata kunci : kecap, kacang merah, kacang kedele 


\section{PENDAHULUAN}

Kecap secara umum merupakan salah satu bahan pangan tradisional berupa cairan berwarna hitam dengan rasa yang manis atau asin dan umumnya terbuat dari kedelai (protein nabati). Melambungnya harga kedelai menimbulkan keresahan bagi industri kecap tradisional yang saat ini masih mengandalkan kedelai impor. Selain itu kebutuhan bahan baku kedelai untuk produksi kecap telah bersaing dengan industri pembuatan tahu tempe sehingga dibutuhkan ketersediaan bahan baku alternatif secara kontinyu. Untuk mengatasi kenaikan biaya produksi dan mengurangi ketergantungan terhadap kedele, maka perlu dicari jenis kacang-kacangan lain yang dapat mensubstitusi kedele, salah satunya adalah kacang merah. Dengan demikian, maka dilakukan penelitian mengenai pemanfaatan kacang merah sebagai substitui kedele pada proses pembuatan kecap manis.

\section{TINJAUAN PUSTAKA}

\section{Kacang Merah}

Kacang merah (Phaseolus vulgaris L) atau kacang jago merupakan varietas dari kacang buncis. Nama umum kacang merah di pasaran internasional adalah Kidney Beans, sedangkan kacang merah yang masih berpolong dan berwarna hijau disebut French Beans atau Snap Beans (Rukmana, 1994). Tanaman kacang merah berbatang pendek setinggi $50-60 \mathrm{~cm}$ dengan bentuk batang berbuku-buku. Tanaman ini dapat tumbuh baik di daerah tropis dengan suhu optimum $16^{\circ}-24^{\circ} \mathrm{C}$ dan curah hujan 500 - $1500 \mathrm{~mm}$ per tahun (Rukmana, 1994). Kacang merah memiliki nilai gizi yang cukup tinggi, baik sebagai sumber protein, karbohidrat maupun sumber vitamin (Direktorat Gizi Depkes RI, 1996). Kandungan protein kacang merah lebih rendah dibanding kedele, dimana kedele mengandung $34.9 \%$, sedangkan kacang merah $23.1 \%$.

\section{Kedele}

Kedele adalah salah satu tanaman polong-polongan yang menjadi bahan dasar banyak makanan dari Asia Timur seperti kecap, tahu, dan tempe. Kedelai 
merupakan sumber utama protein nabati dan minyak nabati dunia. Penghasil kedelai utama dunia adalah Amerika Serikat meskipun kedelai praktis baru dibudidayakan masyarakat di luar Asia setelah 1910. Tanaman kedele dapat tumbuh pada berbagai jenis tanah dengan syarat drainase dan aerasi tanah cukup baik serta kesediaan air yang cukup selama pertumbuhan tanaman. Kedele (Glycine max L) mengandung protein dan lemak berkisar antara 16\% - 20\% (Kanisius, 1989). Koswara (1992) menyatakan bahwa kedele merupakan sumber protein, lemak, vitamin, serat dan mineral. Kedelai sebagai bahan baku kecap mengandung nilai gizi yang cukup tinggi, terutama kandungan protein $(34,9 \%)$ dan karbohidrat $(34,8 \%)$. Asam amino bebas dalam kecap terbanyak adalah asam glutamat. Selain itu, asam amino bebas yang lain adalah aspartat, treonin, serin, prolin, glisin, alanin, valin, isoleusin, leusin, tirosin, fenilalanin, dan lisin, yang jumlahnya berkisar antara 0,01-0,08 g/100 g bahan (Judoamidjojo et al ., 1985). Kandungan asam amino kecap manis Indonesia telah berhasil diidentifikasi oleh Judoamidjojo et al. (1985) dengan menggunakan amino acid analyzer.

\section{Kecap Manis}

Kecap adalah cairan hasil fermentasi bahan nabati atau hewani berprotein tinggi di dalam larutan garam. Kecap manis merupakan produk olahan yang teksturnya kental, berwarna coklat kehitaman, dan digunakan sebagai penyedap makanan (Suprapti, 2005). Bahan baku yang paling banyak diolah menjadi kecap adalah kedelai. Proses pembuatan kecap dapat dilakukan dengan berbagai cara yaitu fermentasi, hidrolisa asam atau kombinasi keduanya, tetapi yang lebih sering dan mudah dilakukan adalah cara fermentasi (Koswara, 1992). Pada cara fermentasi, proses pembuatan kecap melalui dua tahapan, yaitu tahap fermentasi kapang (proses koji) dan fermentasi larutan garam (proses moromi) (Judoamidjojo, 1986).

Sebagian besar kecap Indonesia menunjukkan perbedaan kandungan gula, komposisi asam, dan konsentrasi asam amino yang berhubungan dengan perlakuan fermentasi. Kecap bermutu tinggi adalah : mengandung garam 18\%, gula minimal 40\%, dan pH antara 4.7 - 4.8 (Buckle et al, 1988). Syarat mutu kecap manis menurut SNI 01-3543-1999 adalah : protein minimal 2.5\% dan 
kapang/khamir maksimal 50 koloni/g. Sedangkan kadar protein kecap manis menurut Judoamidjojo (1987) adalah 1.46\%. Kualitas kecap ditentukan oleh kandungan protein. Kadar protein dalam kecap tergantung pada jumlah unsur yang terurai, dimana jumlah unsur yang terurai semakin tinggi jika pelapukan kedelai yang dicapai pada saat fermentasi semakin sempurna.

\section{TUJUAN DAN MANFAAT PENELITIAN}

\section{Tujuan Penelitian}

Penelitian ini bertujuan untuk mengetahui tingkat substitusi kedele dengan kacang merah yang menghasilkan kecap manis sesuai standar mutu dan disukai konsumen.

\section{Manfaat Penelitian}

Sebagai bahan masukan bagi industri kecap bahwa sebagian bahan baku kedele dapat diganti dengan jenis kacang lain, diantaranya kacang merah, dan masukan bagi pemerintah dalam membuat kebijakan terutama dalam hal penyediaan (impor) kedele dan perencanaan pengembangan komoditas pertanian yang mengacu pada penyediaan pangan sesuai dengan pola pangan harapan.

\section{METODE PENELITIAN}

\section{Tempat dan Waktu}

Penelitian ini telah dilakukan di Laboratorium Dasar Universitas Ekasakti Padang dan ATIP pada bulan Agustus sampai September 2006.

\section{Bahan dan Alat}

Bahan baku yang digunakan adalah kedele, kacang merah, dan bahan tambahan pembuatan kecap manis. Bahan kimia digunakan untuk analisa kimia yang disertai dengan peralatan laboratorium.

\section{Rancangan Percobaan}

Rancangan yang digunakan adalah Rancangan Acak Lengkap (RAL) dengan 5 perlakuan dan 3 ulangan. Hasil pengamatan dianalisa berdasarkan uji $\mathrm{F}$ dan kemudian dilanjutkan dengan uji DNMRT pada taraf nyata $5 \%$.

Perlakuan yang digunakan adalah tingkat substitusi kedele dengan kacang merah dengan perbandingan sebagai berikut :

$$
\begin{array}{ll}
\mathrm{A}_{1}=\text { Tingkat substitusi } & 0 \% \quad \text { (kedele }: \text { kacang merah }=100: 10 \text { ) } \\
\mathrm{A}_{2}=\text { Tingkat substitusi } & 10 \% \text { (kedele }: \text { kacang merah }=90: 10 \text { ) }
\end{array}
$$


$\mathrm{A}_{3}=$ Tingkat substitusi $20 \%$ (kedele $:$ kacang merah $=80: 20$ )

$\mathrm{A}_{4}=$ Tingkat substitusi $30 \%$ (kedele $:$ kacang merah $=70: 30$ )

$\mathrm{A}_{5}=$ Tingkat substitusi $40 \%$ (kedele $:$ kacang merah $=60: 40$ )

\section{Pelaksanaan penelitian}

Pembuatan kecap manis berpedoman pada proses pembuatan kecap menurut Koswara (1992), dimana terdiri dari 4 tahapan, yaitu : (1) perebusan kacang, (2) fermentasi kapang, (3) fermentasi garam, dan (4) perebusan filtrat.

Pengamatan :

1. Kadar Protein

2. Jumlah Kapang

3. Uji Organoleptik

\section{HASIL DAN PEMBAHASAN}

\section{Karekteristik Kecap Manis}

Tabel 1. Karakteristik kecap manis dengan berbagai tingkat subtitusi kedele dengan kacang merah.

\begin{tabular}{|c|c|c|}
\hline Perlakuan & Kadar Protein (\%) & $\begin{array}{c}\text { Jumlah Kapang } \\
\text { (koloni/g) }\end{array}$ \\
\hline $\mathrm{A}_{1}$ & $2.39 \quad \mathrm{a}$ & 10 \\
\hline $\mathrm{A}_{2}$ & $2.37 \mathrm{ab}$ & $7.67 \mathrm{~b}$ \\
\hline $\mathrm{A}_{3}$ & $2.06 \mathrm{ab}$ & $4.67 \mathrm{c}$ \\
\hline $\mathrm{A}_{4}$ & $2.04 \mathrm{ab}$ & $1.67 \mathrm{~d}$ \\
\hline $\mathrm{A}_{5}$ & $1.88 \mathrm{ab}$ & $0.67 \mathrm{e}$ \\
\hline
\end{tabular}

Angka yang diikuti huruf kecil yang sama pada lajur yang sama tidak berbeda nyata berdasarkan uji lanjut DNMRT pada taraf nyata 5\%.

\subsection{Kadar Protein}

Hasil analisis statistik menunjukkan bahwa tingkat substitusi kedele dengan kacang merah tidak berpengaruh terhadap kadar protein kecap manis. Tabel 1 memperlihatkan bahwa, semakin besar tingkat substitusi kedele dengan kacang merah, maka semakin rendah kadar protein kecap manis yang dihasilkan. Hal ini berhubungan erat dengan kandungan protein bahan baku, dimana kadar 
protein kacang merah lebih rendah dibanding kedele. Kadar protein kecap manis hasil substitusi kedele dengan kacang merah tidak memenuhi standar mutu yang disayaratkan SNI 01-3543-1999, tetapi memenuhi Standar Kualitas Kecap (SII) kecap manis, yakni kadar protein minimal 2\% (Anonim, 1999), kecuali pada tingkat substitusi $40 \%$. Sedangkan kadar protein kecap manis dengan tingkat substitusi sampai 40\% masih memenuhi syarat menurut Judoamidjojo (1987), yakni $1.46 \%$.

Kadar protein dalam kecap tergantung pada jumlah unsur yang terurai pada proses fermentasi, baik fermentasi koji, maupun fermentasi moromi. Selama fermentasi kapang, kapang akan memproduksi enzim-enzim seperti protease, lipase, dan amilase yang akan memecah protein, lemak, dan pati menjadi senyawa yang lebih swederhana (Rahayu dan Sudarmadji, 1989). Pada fermentasi moromi, terjadi perubahan-perubahan fisik dan kimia yang merupakan lanjutan darim proses koji. Enzim yang dikeluarkan oleh kapang masih bekerja terus, sedangkan kapang mati dalam lingkungan garam. Aktivitas enzim ini mempengaruhi kandungan protein, kadar nitrogen terlarut dan gula pereduksi pada moromi yang dihasilkan (Wijaya, 1988).

\subsection{Jumlah Kapang}

Hasil analisis statistik menunjukkan bahwa tingkat substitusi kedele dengan kacang merah berpengaruh terhadap jumlah kapang kecap manis. Pertumbuhan mikroba tergantung pada subsrat, dimana pertumbuhan kapang lebih optimal pada substrat yang mengandung protein dan bahan lain yang lebih lengkap. Proses pembuatan kecap prinsipnya adalah fermentasi protein yang dilakukan oleh sejenis kapang ( Aspergillus flavus atau Rhizopus oligosporus). Dengan berkurangnya kedele, maka substrat untuk pertumbuhan kapang juga berkurang. Menurut SNI, jumlah kapang kecap manis maksimal 50 koloni/g, sehingga semua kecap manis yang dihasilkan dengan berbagai tingkat substitusi kedele dengan kacang merah memenuhi standar yang disyaratkan.

\section{Uji Organoleptik}

Tabel 2. Skor rata-rata kesukaan panelis terhadap kecap manis.

\begin{tabular}{|c|cc|c|r|}
\hline Perlakuan & \multicolumn{2}{|c|}{ Warna } & Aroma & Rasa \\
\hline $\mathrm{A}_{1}$ & 3.9 (hitam kecoklatan) & 3.8 & 3.6 \\
\hline $\mathrm{A}_{2}$ & 3.8 (hitam kecoklatan) & 3.8 & 3.5 \\
\hline
\end{tabular}




\begin{tabular}{|l|ll|r|r|}
\hline $\mathrm{A}_{3}$ & 3.5 & (hitam kecoklatan) & 3.5 & 3.4 \\
\hline $\mathrm{A}_{4}$ & 3.4 (coklat kehitaman) & 3.3 & 3.3 \\
\hline $\mathrm{A}_{5}$ & 3.3 (coklat kehitaman) & 3.2 & 3.0 \\
\hline
\end{tabular}

Skala berkisar $1-5$, dimana : 1=sangat tidak suka, 2=tidak suka, 3=biasa, 4=suka, 5=sangat suka

Uji organoleptik terhadap warna, aroma, dan rasa pada kecap manis yang dihasilkan terletak pada kisaran angka 3 - 4, yakni pada penilaian biasa sampai hampir suka. Warna coklat-kehitaman pada kecap diperoleh dari gula kelapa atau aren yang digunakan sebagai pemanis, gula pasir yang sengaja dipanasi sehingga berwarna coklat dan membentuk caramel, reaksi browning yang dapat terjadi ketika menjemur hasil fermentasi tahap dua. Cita rasa dan aroma (flavor) kecap yang khas hanya dapat diperoleh dari proses pembuatan kecap secara fermentasi yang memakan waktu berbulan-bulan (minimal satu bulan).

\section{KESIMPULAN DAN SARAN}

1. Kadar protein sampai tingkat substitusi kedele dengan kacang merah sebesar $30 \%$ masih memenuhi syarat mutu kecap manis menurut Standar Kualitas Kecap (SII).

2. Jumlah kapang kecap manis pada semua tingkat substitusi kedele dengan kacang merah memenuhi standar yang disyaratkan.

3. Tingkat kesukaan konsumen (uji organoleptik) terhadap kecap manis yang dihasilkan menurun sejalan dengan berkurangnya penggunaan kedele, berkisar antara biasa sampai suka.

Pada pembuatan kecap manis dengan mengurangi penggunaan kedele dimungkinkan, yakni pengurangan sebanyak 30\%, dan perlu penelitian lanjut dengan menggunakan bahan lain yang mengandung nutrisi cukup untuk pertumbuhan mikroba pengurai.

\section{DAFTAR PUSTAKA}

Anonim. 1999. Standar Kualitas Kecap. Standar Industri Indonesia (SII). Jakarta.

Anonim. 2005. Spesifikasi Persyaratan Mutu Kecap Manis. http://www.Bppjatim.or.id/pagesstandarisasi/kecap-kedelai.php.

Anonim. 1973. Standar Industri Indonesia (SII) 0032-73, Mutu dan Cara Uji Kecap. Departemen Perindustrian RI, Jakarta.

Anonim. 1999. Standar Mutu Kecap Manis. Dewan Standardisasi. Nasional (SNI) 01-3543-1994. Jakarta.

Atjung. 1981. Tanaman yang Menghasilkan Minyak, Tepung dan Gula. CV.Yasaguna. Jakarta

Astawan, M dan M.W. Astawan, 1991. Teknologi Pengolahan Pangan Nabati Tepat Guna. Akademi Presindo, Jakarta. 
Direktorat Gizi Departemen Kesehatan. 1996. Daftar Komposisi Bahan Makanan. Jakarta. Penerbit Bharata.

Israbetyetty. 1993. Pembuatan Kecap dengan Rhizopus oligosporus saito Yang Menggunakan Campuran Kacang Tunggak dan Kacang Kedele pada Lama Fermentasi Yang Berbeda. Tesis. FMIPA Universitas Andalas Padang. Padang.

Koswara,S. 1995. Teknologi Pengolahan Kedele Menjadi Makanan Bermutu cetakan I. Pustaka Sinar harapan. Jakarta.

Mulyokusumo. 1981. Kecap. Penerbit Terate. Bandung.

Rahayu, K dan S.Sudarmadji. 1989. Mikrobiologi Pangan. PAU Universitas. Pangan dan Gizi UGM. Yogyakarta.

Rahman, A. 1992. Teknologi Fermentasi industrial. Bogor :ARCAN

Rukmana, R. 1994. Bertanam Buncis. Penerbit Kanisius. Jakarta.

Wahyuni,R.D. 1999. Studi Pembuatan Cake Dari Campran Tepung Ubi Kayu dan Kacang Merah. Skripsi. Fakultas Pertanian Universitas Ekasakti. Padang.

Winarno, F.G. 1980. Pengantar Teknologi Pangan. PT. Gramedia, Jakarta.

Winarno, F.G. 1980. Enzim Pangan. Pusbangtepa/FTDC-IPB, Bogor. 